\title{
Evaluation of Agricultural Practices Scenarios for Reducing Erosion in Buyo Lake Catchment (Sassandra; Côte d'Ivoire) by Use of GIS
}

\author{
Jean-Jacques Tanoh Koua ${ }^{1}$, Armand Kouao Anoh1, Drissa Tanina Soro1, Jean Kan Kouame², \\ Roger Jean Patrice Jourda ${ }^{2,3}$ \\ ${ }^{1}$ Environment Training and Research Unit, Jean Lorougnon Guédé University, Daloa, Côte d'Ivoire \\ ${ }^{2}$ Earth Sciences and Mineral Resources Training and Research Unit, Felix Houphouet Boigny University, Abidjan, Côte d'Ivoire \\ ${ }^{3}$ University Center for Research and Application in Remote Sensing, Abidjan, Côte d'Ivoire \\ Email: *kouatanoh7@gmail.com
}

How to cite this paper: Koua, J.-J. T., Anoh, A. K., Soro, D. T., Kouame, J. K., \& Jourda, R. J. P. (2019). Evaluation of Agricultural Practices Scenarios for Reducing Erosion in Buyo Lake Catchment (Sassandra; Côte d'Ivoire) by Use of GIS. Journal of Geoscience and Environment Protection, 7, 154-171.

https://doi.org/10.4236/gep.2019.77011

Received: November 21, 2018

Accepted: July 23, 2019

Published: July 26, 2019

Copyright $\odot 2019$ by author(s) and Scientific Research Publishing Inc. This work is licensed under the Creative Commons Attribution International License (CC BY 4.0).

http://creativecommons.org/licenses/by/4.0/

\begin{abstract}
This study has used RUSLE model factors within a GIS component to evaluate eroded soil and developed viable agricultural practices scenarios to reduce soil loss in Buyo Lake catchment in the Western region of Côte d'Ivoire. Consequently, five study cases were tested as following: scenario 1-association of dense forest and crops with a high percentage of mulch; scenario 2-corn and sorghum combination by considering a high yield without conventional tillage; scenario 3-establishment of an herbaceous meadow; and scenario 4-association of palm, coffee, and cocoa with green cover. Scenario $P$ was the setting up of straw mulch after corn or sorghum harvest. The erosion map resulting from these study cases showed by estimation, an average of soil loss of about 95 $\mathrm{t} / \mathrm{ha} /$ year. The respective values obtained for the scenarios 1,2 and 3 are 28 $\mathrm{t} / \mathrm{ha} /$ year, $66 \mathrm{t} / \mathrm{ha} /$ year and $30 \mathrm{t} / \mathrm{ha} /$ year. This indicates a decrease of $68 \%$. By scenario 4 , the estimated average was $2 \mathrm{t} / \mathrm{ha} /$ year corresponding to a decrease of $98 \%$. The combination of scenario 2 with scenario $P$ gave soil losses average of $5 \mathrm{t} / \mathrm{ha} /$ year, i.e. a $95 \%$ reduction. This study shows that the association of palm, coffee, and cocoa with green cover would be very effective in reducing soil loss.
\end{abstract}

\section{Keywords}

Agricultural Practices, Soil Erosion, Scenarios, Buyo Lake Catchment, Côte d'Ivoire

\section{Introduction}

Land is one of the main natural resources related to all human activities and 
sustains development in many countries of the world (Jiang et al., 2014). Thus, rational utilization of the land resource is considered as one of the key conditions for country development. However, today, one notices that land is under threats because of its degradation in the past as well as in the present years (Xu et al., 2012). So that it is important to consider soil erosion as the most serious form of land degradation around the world (Nekhay et al., 2009; Zhang et al., 2010). Because of the galloping urbanization, one is faced with overgrazing, forest destruction and intensive agriculture (DeMeyer et al., 2011). In many areas of the world, the erosion phenomenon has many impacts on land resources. These impacts include water pollution, reservoir sedimentation, degradation of aquatic habitats, the increased cost of water treatment and agricultural production decrease (Park et al., 2011). In tropical areas, erosion by water is a major phenomenon causing land degradation and declining agricultural productivity (Aké et al., 2012). Consequently, the problem of erosion by water is mobilizing the scientific community to find solutions capable of ensuring soils conservation. However, the methods and models used to assess soil erosion have shown in many cases some limitations due to measurement techniques and models (Mbugua, 2009). The advent of new techniques of erosion assessment such as remote sensing and geographic information systems (GIS) allows improving erosion and sediment delivery models. Thus, the prioritization of lands according to their vulnerability to erosion, as well as the development of regional erosion models (Bou et al., 2001; Yjjou et al., 2014), is among the strategies used. In Cote d'Ivoire, the first investigations carried out have analyzed various processes of erosion and erosion control methods. Then, the interest was focused on mapping erosion by water risk (N’go, 2000; Kouadio et al., 2007; N’Dri et al., 2008; Koua, 2014). The recent studies in the watershed of Buyo Lake (West of Côte d'Ivoire), an area with intensive agricultural activities (Koua et al., 2014a) with a coverage rate of over $42 \%$, have highlighted that this area is under threat from erosion by water (N'go, 2000; Kouadio et al., 2007; N’Dri et al., 2008; Koua, 2014); and that there is a veritable issue of water quality in this river basin, especially in Buyo Lake area. The intensification in agriculture has followed population growth (Koua et al., 2013), and growing of fertilizer and pesticides application (Yapo, 2002) to sustain yields. The leaching phenomena and soil erosion that follow are hypothesized as being responsible for the eutrophication of Buyo Lake and agricultural production decrease (Yapo, 2002).

To deal with this situation, this study based upon RUSLE (Revised Universal Soil Loss Equation) model factors, agricultural practices, land conservation scenarios and Geographic Information System (GIS) technics (Dumas, 2010; Hassan et al., 2013) has been conducted. The objective of this work was to develop agricultural practices scenarios with the aim to reducing soil losses in areas with high risk of erosion.

\section{Study Area}

The study area is a forest area located in the South-western Côte d'Ivoire be- 
tween latitude $5^{\circ} 57^{\prime}$ and $8^{\circ} 26^{\prime}$ North and longitudes $6^{\circ} 45^{\prime}$ and $7^{\circ} 51^{\prime}$ West (Figure 1). The basin is located in the Guinean climate zone and its surface is estimated at about $24,560 \mathrm{~km}^{2}$ (Koua et al., 2014b). This zone has two equatorial rainfall maxima (June and September) and belongs to the whole Sassandra River watershed. On average, this watershed has between 2000 to $2500 \mathrm{~mm}$ of precipitation per year (Koua, 2014). According to this author, the monthly average temperature is ranged between $22^{\circ} \mathrm{C}$ and $30.4^{\circ} \mathrm{C}$. The highest temperature $\left(30.4^{\circ} \mathrm{C}\right)$ is observed in March, while the lowest temperature $\left(22^{\circ} \mathrm{C}\right)$ is raised in august (wet months due to the rainy season).

The main geological groups are composed of amphibolite, anorthosite, gneiss, granitoid, itabirite, metasediments, migmatite, metavulcanite and schists. The basin is composed of four (4) main soil types: brown soils, lateritic soils highly desaturated, hydromorphic lateritic soils and lateritic soils moderately desaturated.

Buyo Lake basin favors the development of agriculture and fishing. The development of agriculture has favored strong natural resource degradation by deforestation and the exacerbated agrochemicals use. Indeed, only $17 \%$ of natural forest represented by reserves and protected areas are available against $90 \%$ of primary forest in 1950 (Kouassi, 2001). Degraded areas occupy almost 83\%. Thus, the watershed is not immune to accented erosion by water processes (N'go, 2000; Koua et al., 2013).

\section{Materials and Methods}

\subsection{Materials}

The data used in this study is composed of Digital elevation model, Climate data, Soil data and Land use data.

The field data required for the modeling (flow length, slope gradient, etc.) were all extracted from a DEM. The DEM is from the UTM projection, Zone 30, Northern Hemisphere resolution of $90 \mathrm{~m}$. These were obtained by downloading from

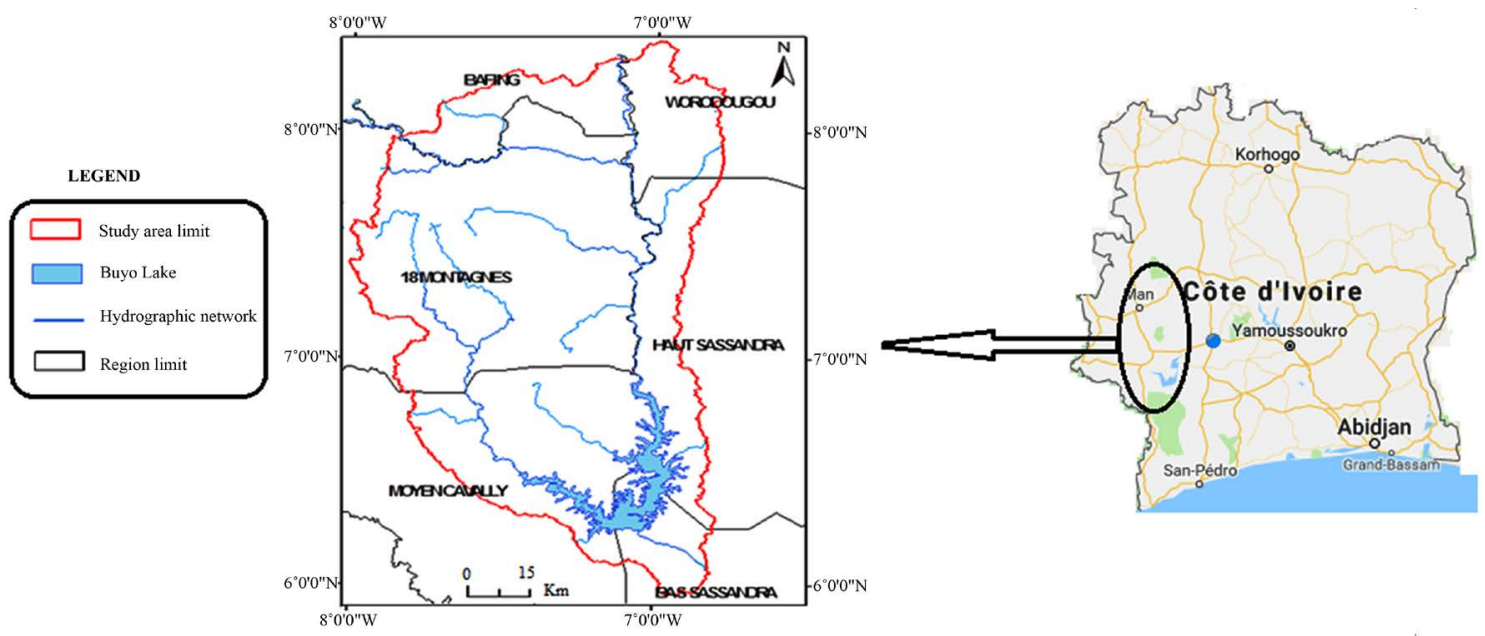

Figure 1. Buyo Lake catchment (Tagini, 1972 modified). 
the internet web site http://srtm.csi.cgiar.org/SELECTION/inputCoord.asp. The elevation range of Buyo Lake basin is from 164 to $1357 \mathrm{~m}$. For this DEM, data were used to estimate the slope gradient, flow direction, catchment area, slope length and flow accumulation with ArcSWAT interface under ArcGIS10 environment.

The climate data used in this study are daily precipitations obtained throughout the http://globalweather.tamu.edu/ SWAT web site at 10 different climate stations. These data cover the period 1980-2010. All the data are provided in DBF format, which can be read as tables by ArcGIS10 or Excel. The precipitation data were used to calculate the rainfall erosivity by interpolating the values from the climate stations. The soil map was obtained mainly from the Harmonized World Soil Database (HWSD) developed by the Food and Agriculture Organization of the United Nations (FAO-UN) at 1/5,000,000 scale (Nachtergaele et al., 2009). Twenty three units of soil are then extracted and completed by additional informations from literature and national soil documents. The soil data have permitted the estimation of the soil erodability factor.

The land use map exploited in this study is for the year 2011 at 1/200,000 scale, and was provided by the CCT (Centre for Mapping and Remote Sensing) of the Centre for Geographic a Numeric Information (CIGN) of the National Office of Technical Study and Development (BNETD). Eight major classes are so identified. The dominant classes are Agricultural land (42.30\%), Range-Brush (29\%) and Forest-Mixed (17.22\%) (Koua et al., 2013). The land use data helped to estimate cover management factor.

\subsection{Methods}

\subsubsection{Model Description}

The RUSLE soil erosion model is used to estimate soil erosion intensity in a catchment. The RUSLE model is based on the USLE erosion model structure which was developed by Wischmeier and Smith (1978), and improved and modified by Renard et al. (1997). Five parameters are used in the RUSLE model to estimate soil loss. These are rainfall Erosivity $(R)$, soil erodability $(K)$, slope length and steepness factor $(L S)$, cover management factor $(C)$, and conservation practice factor $(P)$. Referring to the RUSLE model, the relationship is expressed, as following:

$$
A=R \times K \times L S \times C \times P
$$

where $A\left(\mathrm{t} \cdot \mathrm{ha}^{-1} \mathrm{y}^{-1}\right)$ is the estimated spatial average of total soil loss per year; $R$ $\left(\mathrm{MJ} \cdot \mathrm{mmha}^{-1} \mathrm{~h}^{-1} \mathrm{y}^{-1}\right)$ is the rainfall erosivity factor; $K\left(\mathrm{t} \cdot \mathrm{ha}^{-1} \mathrm{MJ}^{-1} \mathrm{~mm}^{-1} \cdot \mathrm{ha} \cdot \mathrm{h}\right)$ is the soil erodability factor; $L S$ is the slope length and steepness factor (dimensionless); $C$ is the land surface cover management factor (dimensionless); and $P$ is the erosion control conservation practice factor (dimensionless).

\subsubsection{Erosion Factors Calculation}

\section{Rainfall erosivity factor $(R)$}

The rainfall Erosivity factor indicates the erosive force of a specific rainfall 
(Prasannakumar et al., 2012). The relationship between rainfall Erosivity and rainfall developed by Yu and Rosewell (1996) was used to convert the monthly rainfall values to rainfall Erosivity.

The calculation was as follows:

$$
R=3.82 F^{1.41}
$$

where

$$
F(\text { Fournier index })=0.1051 z+37.35
$$

Z. station elevation.

Erosivity values between the rainfall stations were estimated by the use of inverse distance weighting (IDW) interpolation.

\section{Soil erodibility factor $(K)$}

Soil erodibility is, in part a function of its physical properties, texture and structure. The soil resistance to erosion by water is lower for shallow soils as deep soils (Ryan, 1982). The determination of $K$ erodibility factor has been possible due to the size analysis of five major soil types (ferric acrisols, humic ferralsols, eutric cambisols, orthic acrisols and ferralic cambisols) from FAO's database. FAO sizes data were supplemented by analyzes of soil samples obtained in the field. The particle size through the textures triangle allows determining soil texture. The work of Stone and Hilborn (2000) were used to determine the K factor.

\section{Slope length and steepness factor $(L S)$}

The slope and steepness factor $(L S)$ is a combination of slope steepness and slope length, to a high degree affecting the total sediment yield from site.

Prasannakumar et al. (2012) claims, that generating the LS Factor also captures factors like compaction, consolidation and disturbance of the soil. In this study, the $L S$ factors were estimated by applying the equation below (Moore \& Burch, 1986):

$$
L S=(\text { Flow accumulation } \times(\text { cell size }) / 22.13)^{0.4} \times\left(\left(\frac{\text { sinslope }}{0.0896}\right)^{1.4}\right) \times 1.4
$$

Implementation in ArcGIS 10:

$$
\begin{aligned}
L S= & \text { Pow }(\text { "Flow accumulation" } * 90 / 22.13 ; 0.4) \\
& * \text { Pow }(\text { "sinslope" } / 0.0896 ; 1.4) * 1.4
\end{aligned}
$$

where $L S$ is the combination of slope length and steepness, Flow length is the accumulated upslope contribution to a cell, cell size is the resolution of the raster image, and sin slope is the sinus value of the slope in degrees.

The flow length and flow accumulation can be used to estimate the contribution of upstream cells in a DEM to downstream cells. Flow length, also called slope length, helps in estimating the water flow along lines. The estimated $L S$ values based on flow accumulation, varying between 0 and 1522 with an average of 85 .

Cover management factor $(C)$

The cover management factor represents the effect of plants, crop sequence, 
and other soil cover surface on soil erosion. The value of $C$-factor is defined as the ratio of soil loss from a certain kind of land surface cover condition (Wischmeier \& Smith, 1978). The $C$-factor of the watershed varies from 0.001 to 0.5 with the highest values in high farming area. Based on the land use map, Roose (1977), Wischmeier \& Smith (1978), and Omuto (2008) calculated the C-factor in tropical areas (Table 1).

\section{Conservation practice factor $(P)$}

The conservation practice factor $(P)$ is also called as support factor. It represents the soil loss ratio after performing a specific support practice to the corresponding soil loss, which can be treated as the factor representing the effect of soil and water conservation practices (Renard et al., 1997; Omuto, 2008).

The range of $P$ factor varies from 0 to 1 . The lower the value is, the more effective the conservation practices are.

\section{Soil loss estimation}

In order to estimate annual soil loss, the five factors were multiplied according to the relationship in RUSLE model. The soil loss was classified into soil erosion risk maps with five different soil erosion risk levels according to Bamutaze (2010) (Table 2).

\section{Validation of soil loss and erosion risk maps}

Various methods have been used to validate the results of this type of approach, for example: measurement of sediment accumulation in a reservoir, measurement by radioactive tracers and magnetic susceptibility of sediments or direct confrontation with reality on the ground according to adapted visual criteria

Table 1. Value of the factor $C$ depending on the type of coverage.

\begin{tabular}{ccc}
\hline Actual land use type & USLE model land use type & $C$ factor \\
\hline Urban area & UTRN & \\
& URLD & 0.1 \\
URML & \\
Dense forest & FRSE & 0.001 \\
Forest with crops & FRST & 0.1 \\
Crops & AGRR & 0.5 \\
Dense pasture & RNGB & 0.08 \\
Water & WATR & 0.01 \\
\hline
\end{tabular}

Table 2. Soil loss classification.

\begin{tabular}{cc}
\hline Threshold $(\mathrm{t} / \mathrm{ha} / \mathrm{y})$ & Erosion risk \\
\hline Soil Loss $\leq 2$ & Very low \\
$2 \leq$ Soil Loss $\leq 10$ & Low \\
$10 \leq$ Soil Loss $\leq 50$ & Moderate \\
$50 \leq$ Soil Loss $\leq 100$ & High \\
Soil Loss $\geq 100$ & Very high \\
\hline
\end{tabular}


(Bou et al., 2001; Aké et al., 2012). From this point of view, we have adopted the last technique. Because of the lack of experimental work that is difficult to carry out in the field according to the spatial variability of the physical characteristics over large areas of the basin, these changes were recorded as following:

Very low-areas where plant roots are almost completely covered. The vegetation cover is continuous, whether it is forests, thickets, savannah or a simple mulch. Erosion and runoff remain very low despite the aggressiveness of the rains and the inclination of the slope.

Low-areas where the roots of the plants are removed by less than $5 \mathrm{~cm}$ and where the gullies are less than $5 \mathrm{~cm}$ deep and a width of $10 \mathrm{~cm}$.

Moderate-bare tree roots from 5 to $10 \mathrm{~cm}$ and residual soil mounds $15 \mathrm{~cm}$ high with ravines $10 \mathrm{~cm}$ deep and $20 \mathrm{~cm}$ wide.

High-roots of bare trees of more than 15 to $20 \mathrm{~cm}$, pedicles of erosion (columns of earth protected by stones) more than $15 \mathrm{~cm}$ in height and gullies exceeding $30 \mathrm{~cm}$ of depth.

Very high-bare tree roots of more than $20 \mathrm{~cm}$, erosion pedicles (columns of earth protected by stones) more than $20 \mathrm{~cm}$ in height, gullies more than $50 \mathrm{~cm}$ deep spreading over lengths of more than $10 \mathrm{~m}$. Depending on the degree of degradation caused to soil types. The rate of good agreement between the map thus produced and the reality of the terrain is close to $70 \%$.

\section{Analysis of agricultural practices scenarios impacts}

After the modeling of soil losses in Buyo watershed, it was important to design scenarios for farming practices that could be used to reduce soil loss and ensure agricultural productivity for the fight against poverty. When a plant poorly covers the ground, temporarily or continuously, it is possible to associate crops in order to protect soil surface. As part of soil protection against erosion by water, several processes of agricultural practices exist. However, in this study, we examined the association of crops. This method has already been used by Jebari and Bensalah (2014). Several scenarios of agricultural practices were used for this purpose. Scenario 1 corresponds to the association of dense forest and crops with a high percentage of mulch; Scenario 2 is the corn and sorghum combination by considering a high efficiency without conventional tillage; Scenario 3 is an herbaceous meadow and Scenario 4 which corresponds to palm, coffee and cocoa with mulch association. A conservation practice scenario has subsequently been used in this study. This is the scenario $P$ corresponding to the establishment of a straw mulch.

The application of scenario 1 was to replace the strong farming areas (AGRR) subject to a high risk of erosion by dense forest and crops with a high percentage of mulch. In practice, first of all, it is acted to replace the value of the AGRR C-factor by those related to scenario 1 which is about 0.001 (Roose, 1977; Wischmeier \& Smith, 1978). Then the soil losses are recalculated with that value. The application of scenarios 2, 3 and 4 follows the same principle. After that, the scenario $P$ was applied by associating it with the scenario 2 as less effective compared to other scenarios. The use was to replace the value of $P$ factor equal to 1 
in the RUSLE model by those corresponding to the introduction of straw mulch that is 0.01 (Fournier, 1967; Roose \& Sarrailh, 1990).

\section{Results}

The rainfall Erosivity of the study area varies between 1104 and $2342 \mathrm{MJ} \mathrm{mm}$ $\mathrm{ha}^{-1} \mathrm{~h}^{-1} \mathrm{y}^{-1}$. The Northwestern part of the study area has the highest rainfall Erosivity values. All soils of the study area have $\mathrm{K}$ erodibility factor between 0.01 and $0.04\left(\mathrm{t} \cdot \mathrm{ha} \cdot \mathrm{h}^{-1} \mathrm{MJ}^{-1} \mathrm{~mm}^{-1}\right)$. In this study this conservation practice factor was assigned the maximum value of one (1) across the entire study area. The reason for this is that there are no significant conservation practices in the study area. The erosion risk map obtained by RUSLE model showed soil loss between 0 and $4185 \mathrm{t} / \mathrm{ha}$ /year, with an average of $95 \mathrm{t} / \mathrm{ha} /$ year. Areas with a major loss were Gbonné, Man, Biankouma Facobly (Mountains Region) (Figure 2). The classification of soil losses estimates has showed five classes of soil erosion risk (Figure 3); $23 \%$ of the area was at very high risk; $24 \%$ of the study area are occupied by high risk; the moderate risk is occupied by $33 \%$ of the basin area; the low risk was has represented $11 \%$ against $9 \%$ occupied by very low risk. Around the Buyo Lake dam, there was also a high risk of soil erosion which has induced a risk of pollution in the Buyo Lake. Areas with high and very high risk were characterized by a steep slope ( $>50 \%)$, low vegetation cover due to agriculture. Areas with low and very low risk were characterized by low slopes and dense vegetation

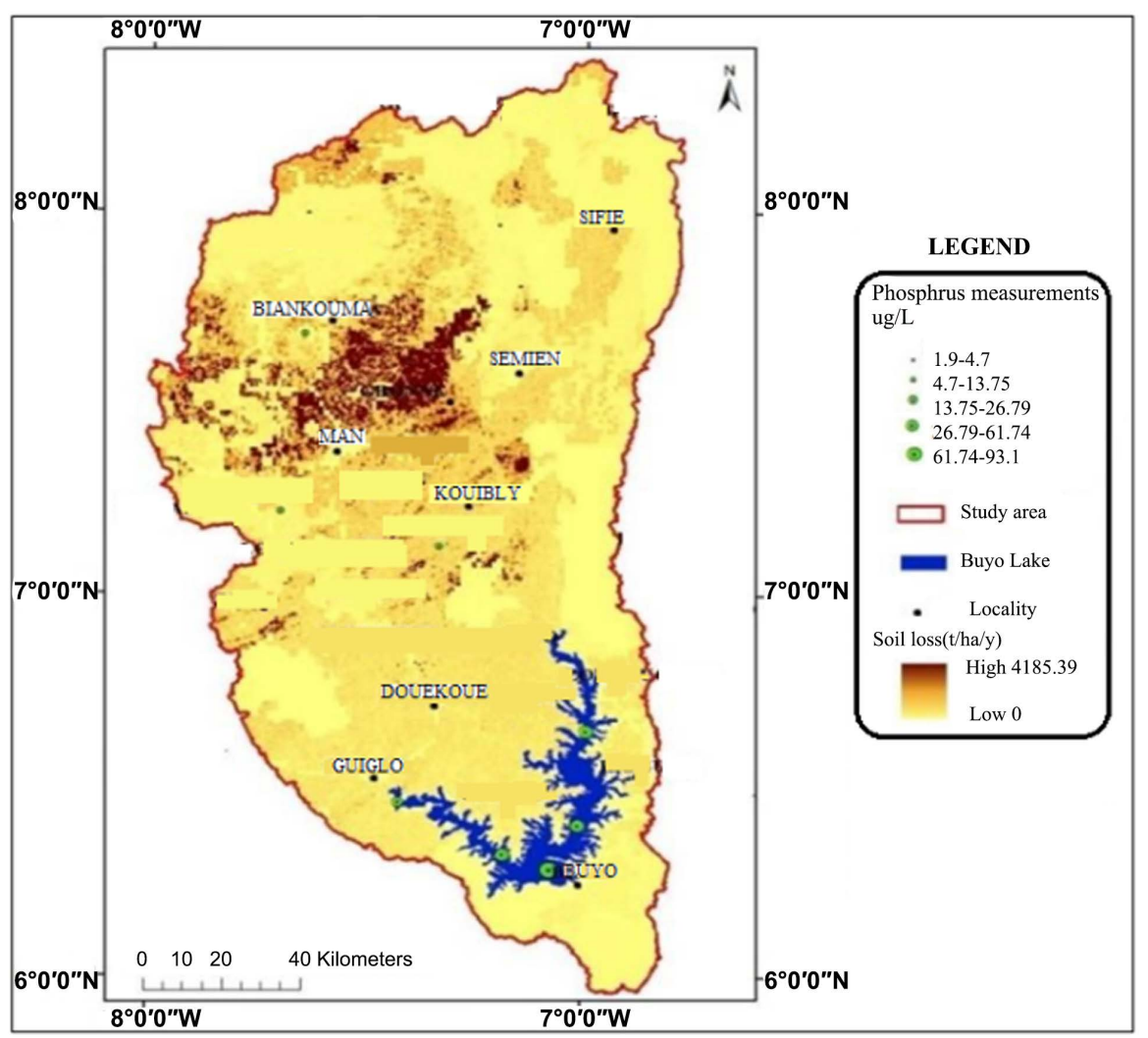

Figure 2. Soil losses (RUSLE) and field phosphorus quantities variation map. 


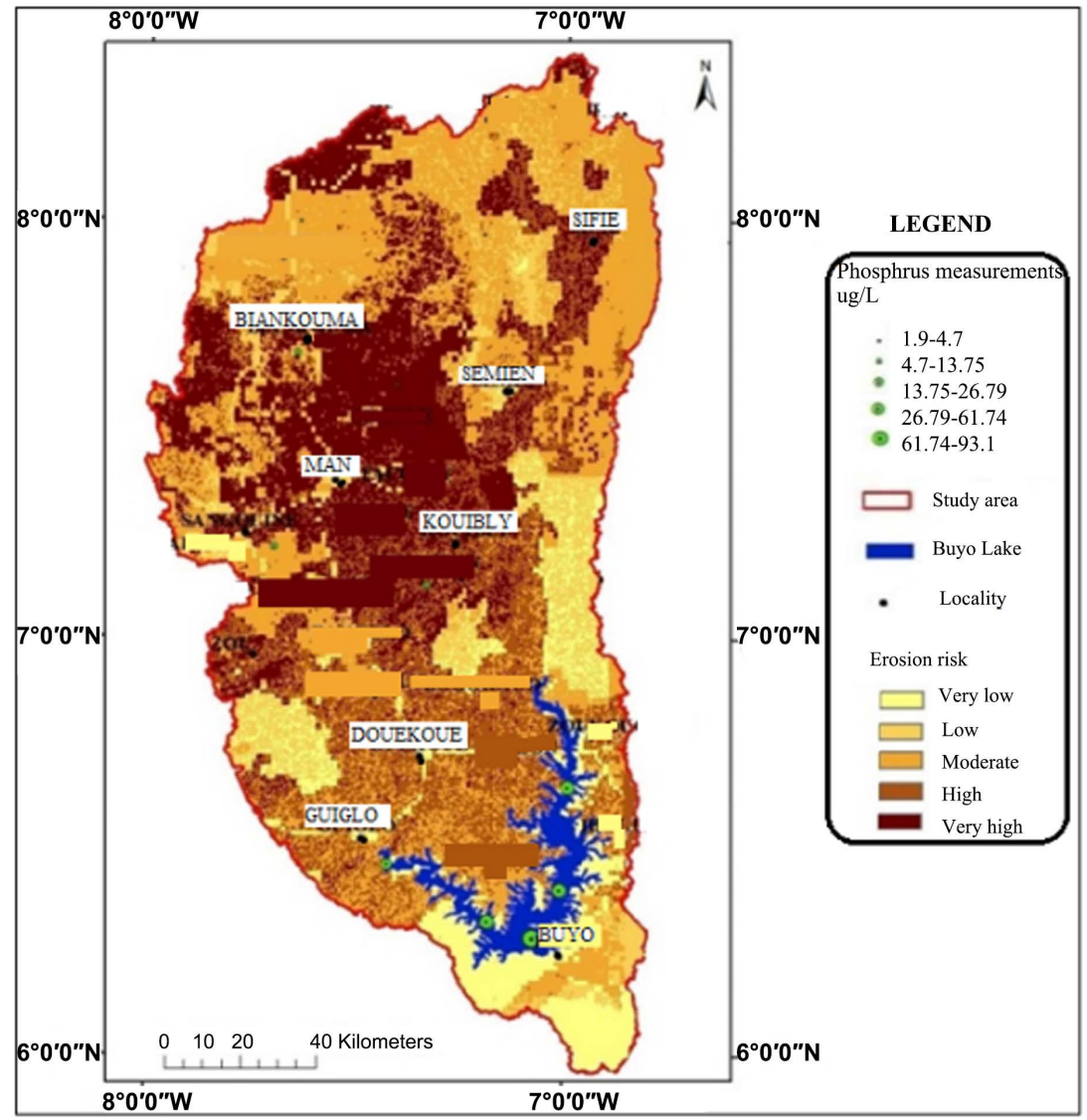

Figure 3. Soil losses (RUSLE) and field phosphorus quantities variation map.

cover (dense forests). These areas were mainly observed in the southern part of the watershed. The sediments eroded upstream agricultural lands are drained downstream Buyo Lake dam. This causes problems of sedimentation and eutrophication.

This situation can be explained by phosphorus field measurements level that prove a weak upstream Buyo Lake because erosion is strong. These rates vary from 1.9 to $13.75 \mu \mathrm{g} / \mathrm{L}$. At Buyo Lake, analyzes showed rates ranging up to 93 $\mu \mathrm{g} / \mathrm{L}$ due to sediments deposition delivered from upstream to the Lake.

The results of erosion risk under scenarios study are summarized in Table 3 and Table 4. The risk map obtained with scenario 1 (Figure 4) shows soil losses ranging from 0 to $1552 \mathrm{t} /$ ha/year, with an average of $28 \mathrm{t} / \mathrm{ha} /$ year, a reduction of $71 \%$, compared to the reference map. The classification of soil loss under this scenario showed $57 \%$ with very low risk, $10 \%$ at low risk, $22 \%$ of moderate risk, $4 \%$ of high risk and $7 \%$ of the basin correspond to very high risk. Like the reference map, in this scenario, we noted, that high risk and very high risk are mainly concentrated in the mountain region, a strong farming area. However, this scenario allowed a conversion of high risk and very high risk to low and very low risk in the area around Buyo Lake dam. Thus, the scenario 1 has increased the very low risk of $48 \%$ compared with the reference, reducing considerably high and very high risk to $20 \%$ and $16 \%$, respectively. 
Table 3. Soil loss and erosion risk under scenarios.

\begin{tabular}{cccccc}
\hline \multicolumn{2}{c}{ Reference maps (RUSLE) } & \multicolumn{2}{c}{ Scenario 1 (Figure 4) } & \multicolumn{2}{c}{ Scenario 2 (Figure 5) } \\
\hline $\begin{array}{c}\text { Soil loss (Figure 2) } \\
(\mathrm{t} / \mathrm{ha} / \mathrm{y})\end{array}$ & $\begin{array}{c}\text { Erosion risk } \\
(\text { Figure } 3)(\%)\end{array}$ & $\begin{array}{c}\text { Soil loss } \\
(\mathrm{t} / \mathrm{ha} / \mathrm{y})\end{array}$ & Erosion risk $(\%)$ & $\begin{array}{c}\text { Soil loss } \\
(\mathrm{t} / \mathrm{ha} / \mathrm{y})\end{array}$ & Erosion risk $(\%)$ \\
\hline Low: 0 & Very low: 9 & Low: 0 & Very low: 57 & Low: 0 & Very low: 12 \\
High: 4185 & Low: 11 & High: 1552 & Low: 10 & High: 2415 & Low: 9 \\
Average: 95 & Moderate: 33 & Average: 28 & Moderate: 22 & Average: 66 & Moderate: 49 \\
& High risk: 24 & & High risk: 4 & & High risk: 17 \\
& Very high risk: 23 & & Very high risk: 7 & & Very high risk: 13 \\
\hline
\end{tabular}

Table 4. Soil loss and erosion risk under scenarios (continued from Table 3).

\begin{tabular}{cccccc}
\hline \multicolumn{2}{c}{ Scenario 3 (Figure 6) } & \multicolumn{2}{c}{ Scenario 4 (Figure 7) } & \multicolumn{2}{c}{$\begin{array}{c}\text { Scenario 2 and Scenario } P \\
\text { (Figure } 8)\end{array}$} \\
\hline $\begin{array}{c}\text { Soil loss } \\
(\mathrm{t} / \mathrm{ha} / \mathrm{y})\end{array}$ & Erosion risk (\%) & $\begin{array}{c}\text { Soil loss } \\
(\mathrm{t} / \mathrm{ha} / \mathrm{y})\end{array}$ & Erosion risk (\%) & $\begin{array}{c}\text { Soil loss } \\
(\mathrm{t} / \mathrm{ha} / \mathrm{y})\end{array}$ & Erosion risk $(\%)$ \\
\hline Low: 0 & Very low: 38 & Low: 0 & Very low: 88 & Low: 0 & Very low: 43 \\
High: 1552 & Low: 27 & High: 111 & Low: 7 & High: 242 & Low: 49 \\
Average: 30 & Moderate: 24 & Average: 2 & Moderate: 5 & Average: 5 & $\begin{array}{c}\text { Moderate: } 7 \\
\end{array}$ \\
& High risk: 4 & & & & High risk: 1 \\
& Very high risk: 7 & & & & Very high risk: 0.3 \\
\hline
\end{tabular}

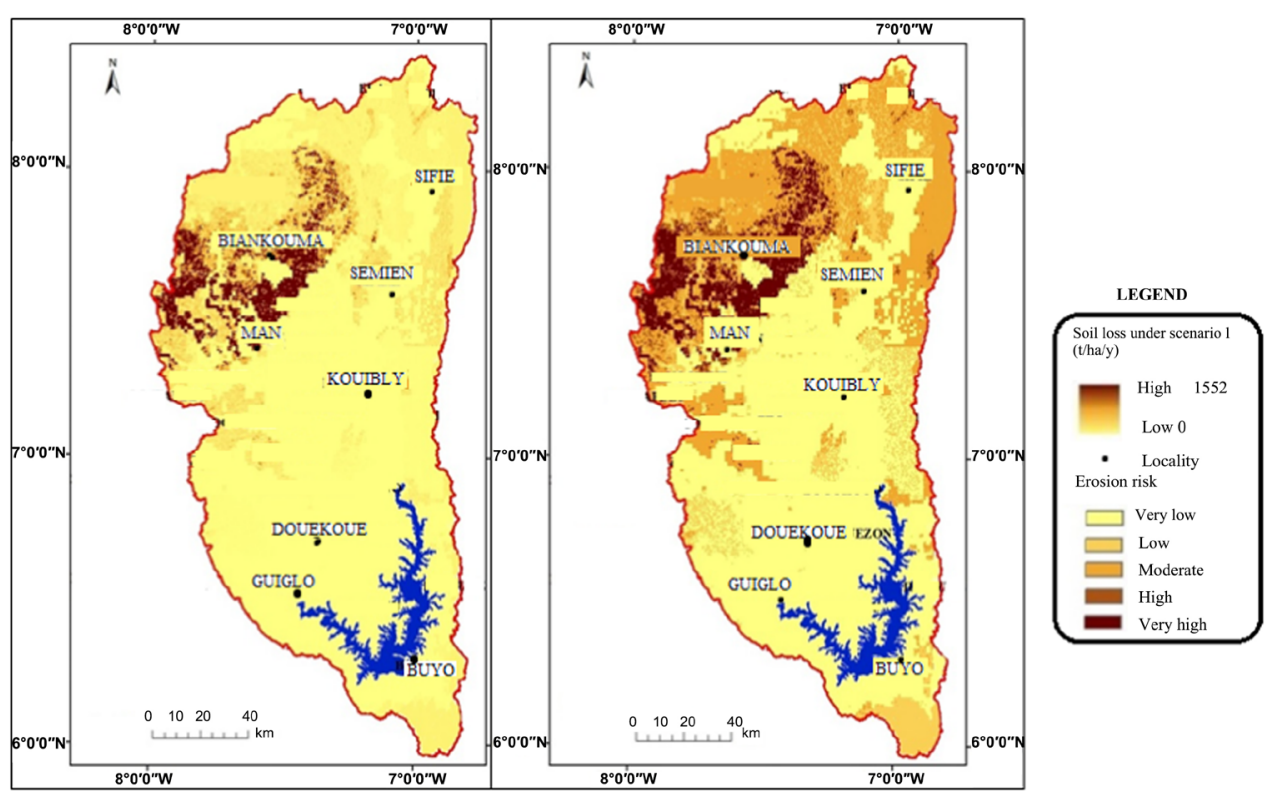

Figure 4. Erosion under scenario 1 (dense forest and crops with a high percentage of mulch association).

Soil losses using the scenario 2 (Figure 5) vary from 0 to $2415 \mathrm{t} / \mathrm{ha} / \mathrm{y}$, with an average of $66 \mathrm{t} / \mathrm{ha} / \mathrm{y}$, a reduction of $31 \%$ compared with the reference. The application of scenario 2 gave an erosion risk map with $12 \%$ of very low risk, low risk of $9 \%, 49 \%$ at moderate risk, $17 \%$ of high risk and $13 \%$ at very high risk. Under scenario 2, we noticed, also, that central and western parts of the basin 


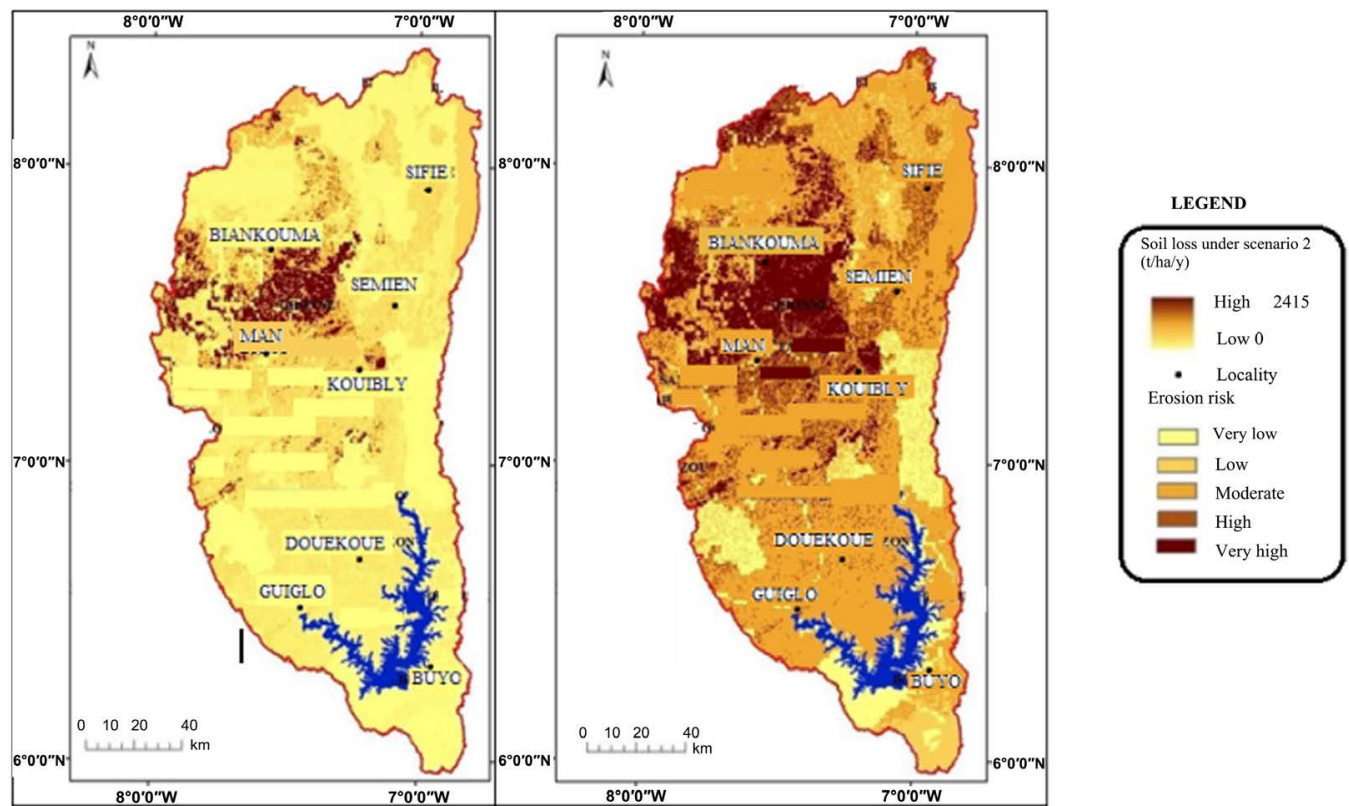

Figure 5. Erosion under scenario 2 (maize and sorghum association considering high efficiency).

were at higher risk of erosion. This can be explained by mountains slopes and agricultural activities. However, there was a decrease in high and very high risk of 7 and 10\% respectively in benefit of moderate risk which increased from 33 to $49 \%$, a gain of $16 \%$. Compared with scenario 1 , scenario 2 was considered less effective, but can be used to fight against erosion in agricultural land of this region.

Soil losses estimated using scenario 3 were ranged from 0 to $1552 \mathrm{t} / \mathrm{ha} / \mathrm{y}$, with an average of $30 \mathrm{t} / \mathrm{ha} / \mathrm{y}$ (Figure 6). The results obtained under this scenario were similar to those from the scenario 1 . It was noted indeed a $68 \%$ reduction compared to the reference. The risk map obtained showed $7 \%$ at very high risk, $4 \%$ of high risk, $24 \%$ of the basin at moderate risk, $27 \%$ and $38 \%$ respectively of low risk and very low risk. The simulation of soil loss under scenario 1 has used the setting up of dense forest and crops with a high percentage of mulch association, whereas the scenario 3 used a grassy meadow. Both types of land cover were dense and permanent. By their density, they almost had the same function in the fight against soil loss. This could explain the similar values.

The soil losses estimates under scenario 4 (Figure 7) evolved from 0 to 111 $\mathrm{t} / \mathrm{ha} / \mathrm{y}$. These estimates with an average of $2 \mathrm{t} / \mathrm{ha} / \mathrm{y}$ indicated a low sediment loss of $98 \%$ compared to the reference map. Unlike the other scenarios, this scenario had three risk levels: $5 \%$ of moderate risk, $7 \%$ of low risk against $88 \%$ of very low risk. For the scenario 4 , the high and very high risks have disappeared. In fact, the very low risk was increased up to $88 \%$. Thus, the scenario 4 has proved the most efficient agricultural practices scenarios. Indeed, the palm, coffee, cocoa and plant cover association have allowed the recovery of the natural vegetation that limits erosion. The scenario of the least efficient agricultural practice remained the scenario 2 . 


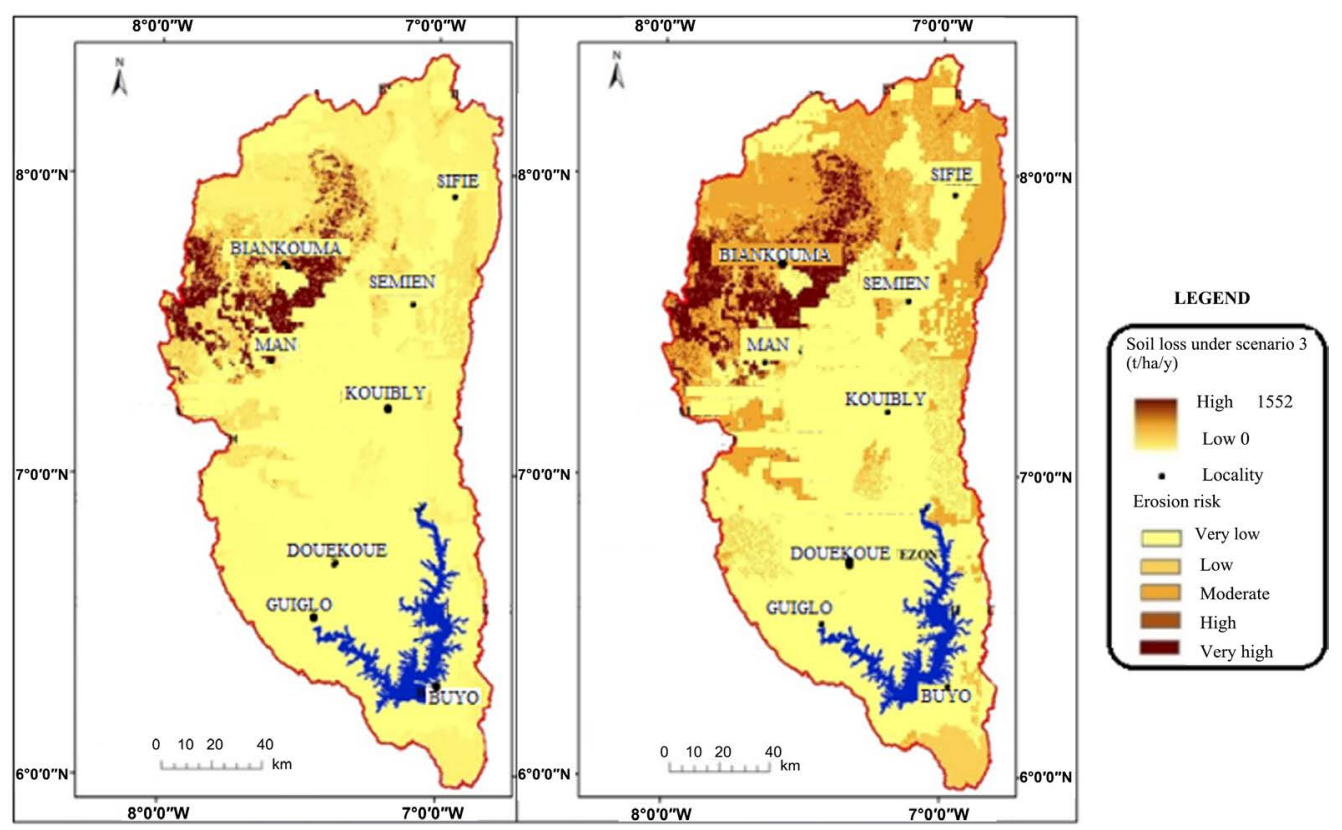

Figure 6. Erosion under the scenario 3 (herbaceous meadow).
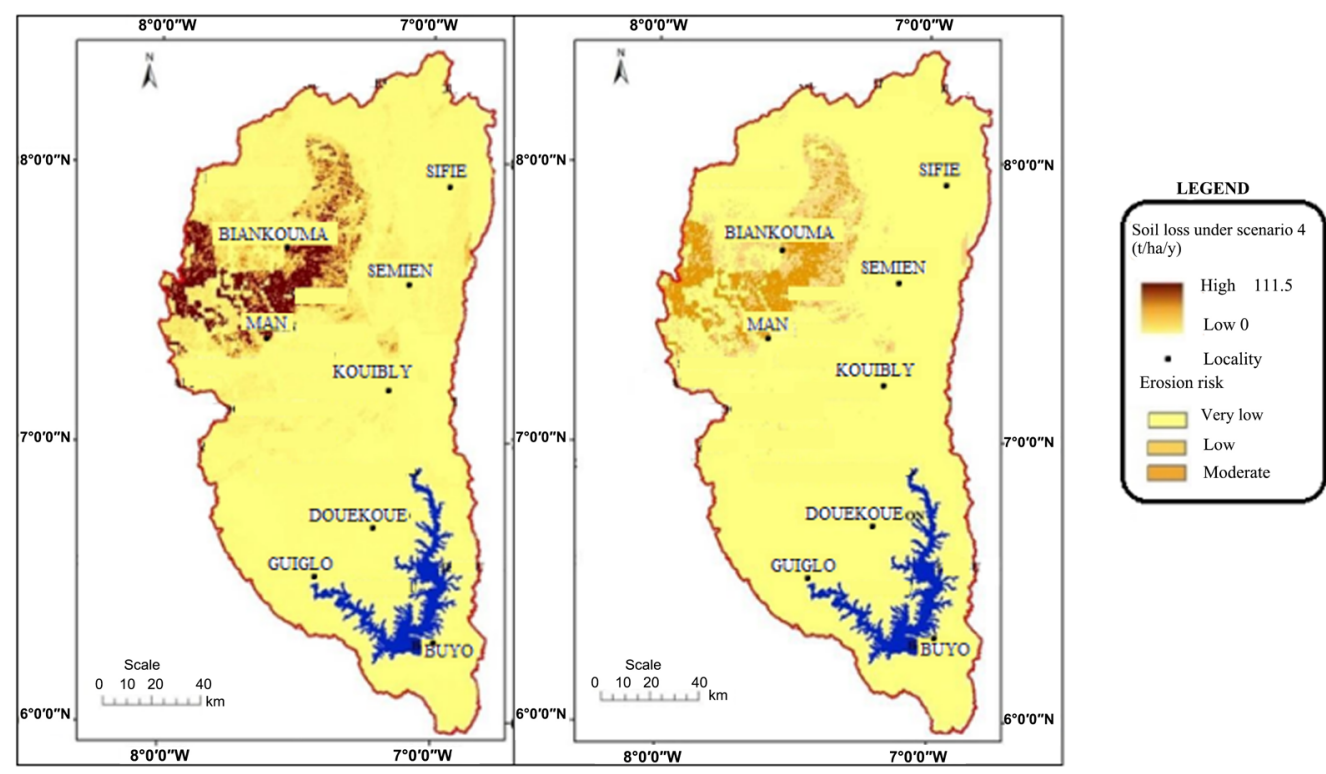

Figure 7. Erosion under scenario 4 (palm, coffee, cocoa with mulch association).

Soil loss map obtained by the combination of scenario 2 and scenario $P$ indicated that sediments losses were ranged from 0 to $242 \mathrm{t} / \mathrm{ha} / \mathrm{y}$ on the entire watershed (Figure 8). The average of these losses was $5 \mathrm{t} / \mathrm{ha} / \mathrm{y}$, a $95 \%$ reduction compared to the reference map. The categorization of these soil losses gave 5 levels of erosion risk: very high (0.3\%), high (1\%), moderate (7\%), low (49\%) and very low (43\%). For this scenario, we noticed, that high risk and very high risk were occupied a very thin part of the catchment area (1.3\%). It was thus possible to increase the low and very low risks of respectively 38 and $34 \%$ compared to the reference. 


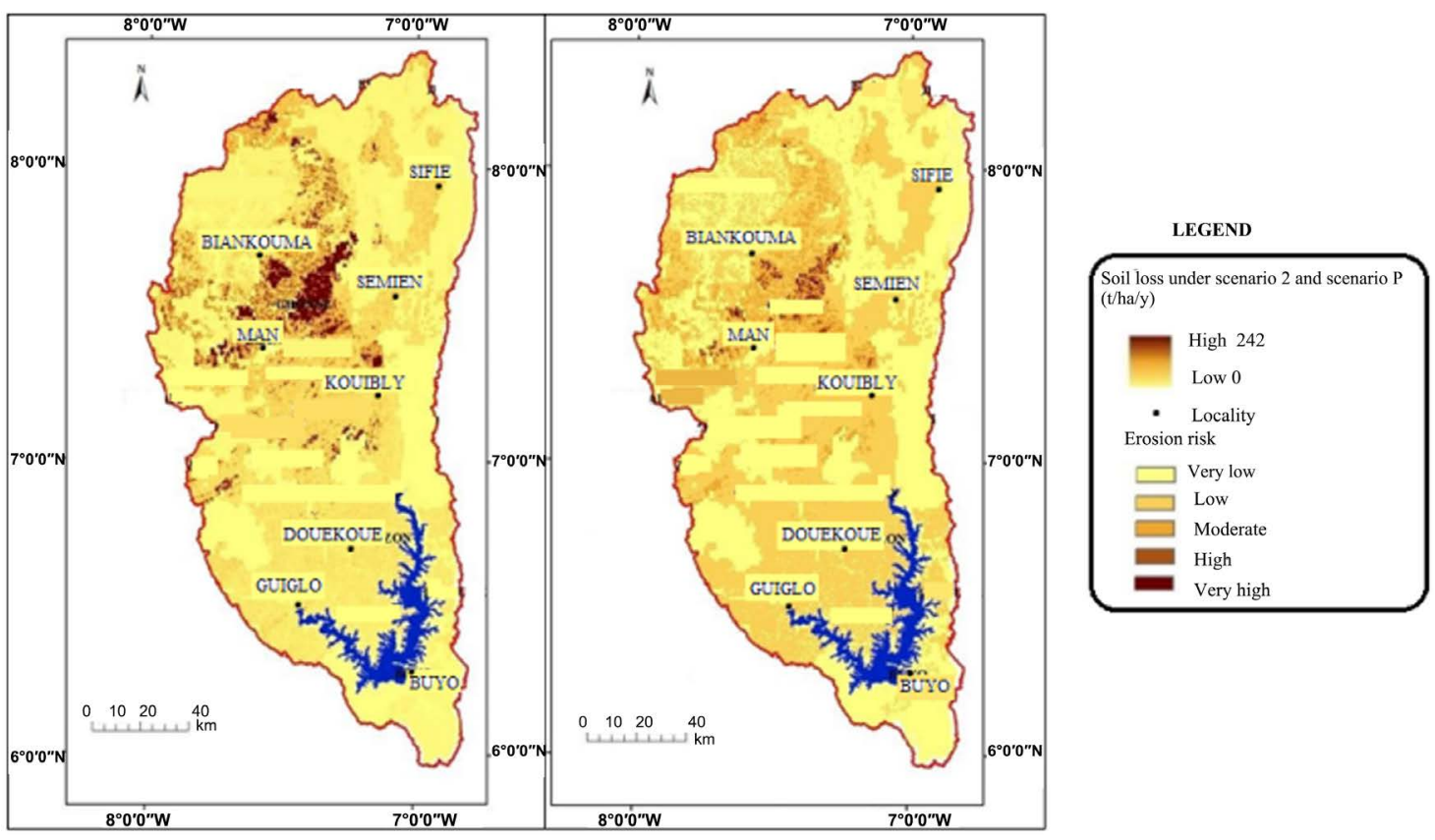

Figure 8. Erosion under combination of scenario 2 and scenario $P$.

The establishment of straw mulch after corn and sorghum harvest in areas with high agricultural activities is very effective in the fight against erosion by water. The results showed the impact of the vegetation cover on soil loss in the study area. The farming practices scenarios simulated indicated that the most effective is the scenario 4 (palm, coffee, cocoa with mulch association), followed by scenario 2 and scenario $P$ combination, then come the scenarios 1 and 3 ; the least effective scenario is the scenario 2 (Figure 9).

\section{Discussion}

Precipitations data used come from 10 climate stations. The interpolation of these pluviometric data which are not only specific to Buyo Lake watershed may, also, induce uncertainties that could influence the modeling. However, a large number of climate stations are essential to consolidate our results. Regarding soil and land use maps, the major problem remains the scale. The soil map has a scale of $1 / 5,000,000$ that is very rough. The scale of the land use map whereas is $1 / 200,000$. These coarse scales generate losses of information on the maps and cause uncertainties in the soil erosion risk model. Nevertheless, the interest of this study was to produce preliminary erosion risk maps and propose simple methods less expensive in the fight against soil erosion, incorporating the essential parameters of the watershed using an accessible model. These maps should represent a basic support in the fight against erosion and eutrophication in the Buyo Lake watershed.

The high and very high risks identified in the central, western, northern zones of the study area and the one around Buyo Lake can be explained, firstly, by agricultural activities which cause degradation and vegetative cover reduction 


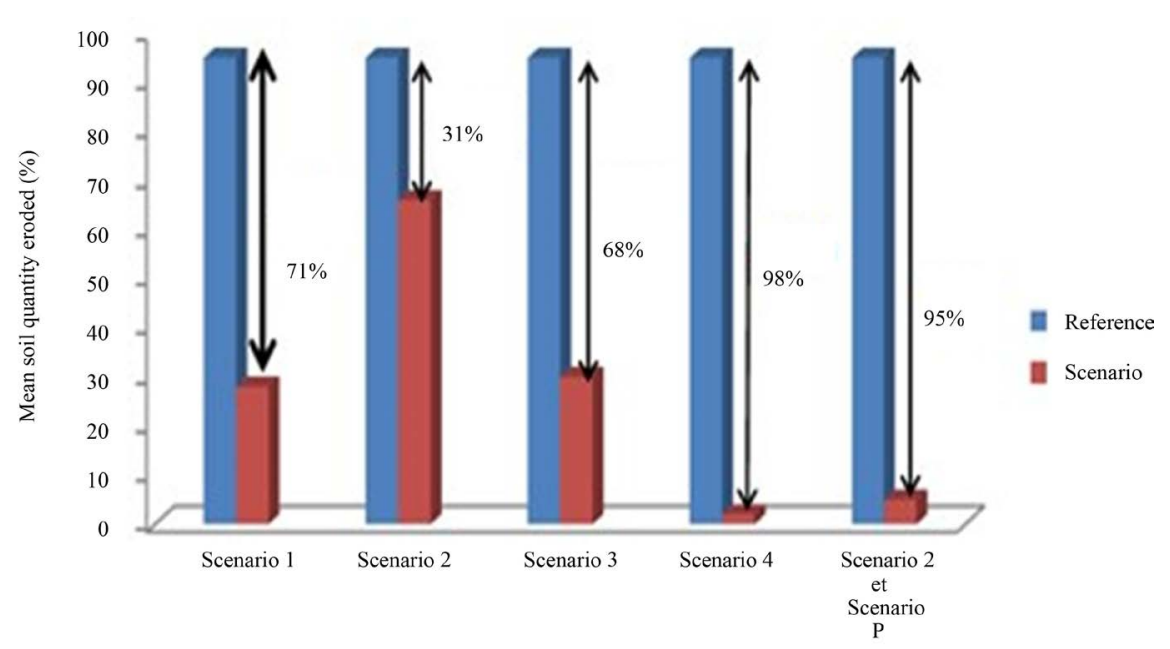

Figure 9. Estimated average soil loss with the different scenarios tested.

and secondly by steep slopes on the mountains sides in the Mountain Region. Recent studies by Koua et al. (2013) showed, that agricultural land occupies over $42 \%$ of Buyo lake versant. The results of this study corroborate those of Kouadio et al. (2007), which showed the decrease in vegetation cover and high risk and very high risk of soil erosion by water in these regions. The high risk and very high risk are located in the Man zone and Man upstream zone characterized by a Mountain.

Moreover, the dominance of degraded range lands and crop areas are considered very sensitive to erosion (Yjjou et al., 2012a). In Buyo Lake basin, although agriculture is developed, no practice is done for soil conservation, while contour plowing, ridging, or contour ridging are anti-erosion practices that limit runoff and erosion (Payet et al., 2011). In addition, according to Yjjou et al. (2012b), the slope values are highest near the banks. This is why a very high risk is highlighted in the area around Buyo Lake. If the decrease of vegetation cover causes erosion, its increase reduces runoff velocity and limits erosion phenomena by increasing infiltration (Rios, 2010). According to this author, forests characterize areas of very low sensitivity, while arable land characterizes areas of high sensitivity to erosion. Grasslands and forests are protective of the soil from erosion. The works from Hassan et al. (2013) in the western Bekaa in Lebanon have, also, revealed the importance of vegetation in the fight against erosion. According to authors mentioned above, the territories covered by dense forests, which cover about $90 \%$ of the surface, no suffers physiological change during periods when rainfall intensity is higher. This is what explains the very low, low and moderate risks observed in some places characterized by the presence of dense forests and dense vegetation. In that concern, the model implemented in our study showed the importance of the vegetation cover in the fight against soil erosion by water in agricultural areas. Generally, all tested scenarios enabled to minimize the erosion risk.

At the issue of analysis of all tested scenarios, we notice that the mountain Re- 
gion in the studied zone (western and central parts of the catchment area) remains the most exposed to the phenomenon of soil erosion by water as, also, describe Kouadio et al. (2007). However, the availability and quality of data often impact the results. Indeed, we are in general faced with the DEM resolution problem. In our study, the DEM used has a resolution of $90 \mathrm{~m}$ may cause relative over estimation of LS factor. A resolution of 25 - $30 \mathrm{~m}$ would be more desirable to avoid loss of information and strengthen the model.

\section{Conclusion}

The results of this study indicate that the Mountain Region of the Western of Cote d'Ivoire has a high to very high risk of soil erosion by water, respectively, of $23 \%$ and $24 \%$ in the Buyo Lake watershed. The significant potential losses of soil found in that region predispose waterbody of this dam to sedimentation and eutrophication. Agricultural practices for the tested scenarios against erosion have shown their efficiency in general. However, the most effective is the scenario 4 and the combination of scenario 2 and scenario $P$. These scenarios have reduced until $98 \%$ and $95 \%$, respectively, the average soil loss compared with the reference. The establishment of crops such as palm, coffee, cocoa, dense vegetative cover and a mulch of straw after corn and sorghum harvests in areas of high agricultural activity is very effective for minimize soil erosion by water. These practices may be recommended in this watershed or other agricultural watersheds for integrated natural resources (water and soil) management for the welfare of the environment and water bodies in river or lacustrine catchment areas in similar relief zones.

\section{Acknowledgements}

The authors wish to thank Professor Lane Stuart, the Director of Earth Surface Dynamics Institute at University of Lausanne (Switzerland) for his beneficial suggestions. This work was supported in part by grants from PASRES (Scientific Research Strategic Support Program of Côte d'Ivoire) and Swiss Confederation.

\section{Conflicts of Interest}

The authors declare no conflicts of interest regarding the publication of this paper.

\section{References}

Aké, G. E., Kouadio, B. H., Adja, M. G., Etien, J., Effébi, K. R., \& Biémi, J. (2012). Cartographie de la vulnérabilité multifactorielle à l'érosion hydrique des sols de la région de Bonoua (Sud-Est de la Côte d'Ivoire). Physio-géo, 6, 1-42. https://doi.org/10.4000/physio-geo.2285

Bamutaze, Y. (2010). Patterns of Water Erosion and Sediment Loading in Manafwa Catchment, Mt. Elgon, Eastern Uganda. PhD Thesis, Elgon: Makerere University.

Bou, K., Girad, M. C., Shaban, A., Khawlie, M., Faour, G., \& Darwich, T. (2001). Apport de la télédétection pour la modélisation de l'érosion hydrique des sols dans la région 
côtière du Liban. Télédétection, 2, 79-90.

DeMeyer, A., Poesen, J., Isabirye, M., Deckers, J., \& Raes, D. (2011). Soil Erosion Rates in Tropical Villages: A Case Study from Lake Victoria Basin, Uganda. Catena, 84, 89-98. https://doi.org/10.1016/j.catena.2010.10.001

Dumas, P. (2010). Méthodologie de cartographie de la sensibilité des sols à l'érosion appliquée à la région de Dumbéa à Païta-Bouloupari (Nouvelle-Calédonie). Les Cahiers d'Outre-Mer, 252, 567-584. http://com.revues.org/6123 https://doi.org/10.4000/com.6123

Fournier, F. (1967). Factors of Soil Erosion by Water; Research on Soil Conservation in Africa and Madagascar. African Soils, 12, 6-51.

Hassan, H., Touchart, L., \& Faour, G. (2013). La sensibilité potentielle du sol à l'érosion hydrique dans l'ouest de la Bekaa au Liban. https://hal.archives-ouvertes.fr/hal-01962928/document

Jebari, S., \& Bensalah, R. (2014). Protection des terres céréalières contre l'érosion hydrique. In Proceedings of Journée Nationale sur la valorisation des Résultats de la Recherche dans le Domaine des Grandes Cultures (p. 59). Tunis: Institution de la Recherche et de l'Enseignement Supérieur Agricoles.

Jiang, B., Bamutaze, Y., \& Pilesjö, P. (2014). Climate Change and Land Degradation in Africa: A Case Study in the Mount Elgon Region, Uganda. Geo-Spatial Information Science, 17, 39-53. https://doi.org/10.1080/10095020.2014.889271

Koua, T. J. (2014). Apport de la modélisation hydrologique et des Systèmes d'Information Géographique (SIG) dans l'étude du transfert des polluants et des impacts climatiques sur les ressources en eau: cas du bassin versant du lac de Buyo (Sud-ouest de la Côte d'Ivoire). PhD Thesis, Abidjan: Felix Houphouët Boigny University of Cocody.

Koua, T. J., Jourda, J. P., Kouame, K. J., \& Anoh, K. A. (2013). Assessment of Sediment and Pollutants in Buyo Lake, Ivory Coast, Using SWAT (Soil and Water Assessment Tool) Model. Journal of Chemistry and Chemical Engineering, 7, 1054-1059.

Koua, T. J., Jourda, J. P., Kouamé, K. J., Anoh, K. A., Balin, D., \& Lane, S. (2014b). Potential Climate Change Impacts on Water Resources in the Buyo Lake Basin (Southwest of Ivory Coast). International Journal of Innovation and Applied Studies, 8, 1094-1111.

Koua, T. J., Jourda, J. P., Kouame, K. J., Anoh, K. A., N’Dri, W. K., Lazar, G., \& Lane, S. (2014a). Effectiveness of Soil and Water Assessment Tool Model to Simulate Water Flow in a Large Agricultural Complex Watershed: Case of Buyo Lake Basin, West of Côte d'Ivoire. Environmental Engineering and Management Journal, 13, 1735-1742. https://doi.org/10.30638/eemj.2014.193

Kouadio, B. H., Kouamé, K. F., Saley, B. M., Biémi, J., \& Ibrahima, T. (2007). Insécurité climatique et géorisques en Côte d'Ivoire: Étude du risque d'érosion hydrique des sols dans la région semi-montagneuse de Man (Ouest de la Côte d'Ivoire). Sécheresse, 18, 29-37.

Kouassi, A. (2001). Pressions anthropiques et impacts socio-économiques et spatioécologiques dans l'espace Buyo (Côte d'Ivoire). Thèse de Doctorat unique, Abidjan: Université d'Abobo-Adjamé, Côte d'Ivoire.

Mbugua, W. (2009). Using GIS Techniques to Determine Rusle's " $R$ " and "LS" Factors for Kapingazi River Catchment. Master Thesis, Kiambu: Jomo Kenyatta University of Agriculture and Technology, Kenya.

Moore, I. D., \& Burch, G. J. (1986). Physical. Basis of the Length Slope Factor in the Universal Soil Loss Equation. Soil Science Society of America Journal, 50, 1294-1298.

https://doi.org/10.2136/sssaj1986.03615995005000050042x 
N’Dri, B. E., N’go, Y. A., Kadio, H. N., Ouatara, A., Touré, B., \& Biémi, J. (2008). Effect of Soil Slope and Cover on Runoff and Rate Soil Loss from Experimental Plots in Area of Attécoubé. European Journal of Scientific Research, 21, 459-470.

N'go, Y. A. (2000). Contribution à l'étude de l'érosion des sols dans le bassin versant de Sassandra (région de Buyo): Analyse des facteurs et évaluation des risques avec télédétection et systèmes d'information géographique. $\mathrm{PhD}$ Thesis, Abidjan: University of Abobo-Adjame, Côte d'Ivoire.

Nachtergaele, F., Velthuizen, H. V., \& Verest, L. (2009). Harmonized World Soil Database Version 1.

http://www.fao.org/fileadmin/templates/nr/documents/HWSD/HWSD_Documentatio n.pdf

Nekhay, O., Arriaza, M., \& Boerboom, L. (2009). Evaluation of Soil Erosion Risk Using Analytic Network Process and GIS: A Case Study from Spanish Mountain Olive Plantations. Journal of Environmental Management, 90, 3091-3104.

https://doi.org/10.1016/j.jenvman.2009.04.022

Omuto, C. T. (2008). Assessment of Soil Physical Degradation in Eastern Kenya by Use of a Sequential Soil Testing Protocol. Agriculture, Ecosystems \& Environment, 128, 199-211. https://doi.org/10.1016/j.agee.2008.06.006

Park, S., Oh, C., Jeon, S., Jung, H., \& Choi, C. (2011). Soil Erosion Risk in Korean Watersheds, Assessed Using the Revised Universal Soil Loss Equation. Journal of Hydrology, 399, 263-273. https://doi.org/10.1016/j.jhydrol.2011.01.004

Payet, E., Dumas, P., \& Pennober, G. (2011). Modélisation de l'érosion hydrique des sols sur un bassin versant du sud-ouest de Madagascar, le Fiherenana. Vertig O, 11. https://doi.org/10.4000/vertigo.12591

Prasannakumar, V., Vijith, H., Abinod, S., \& Geetha, N. (2012). Estimation of Soil Erosion Risk within a Small Mountainous Sub-Watershed in Kerala, India, Using Revised Universal Soil Loss Equation (RUSLE) and Geo-Information Technology. Geoscience Frontiers, 3, 209-215. https://doi.org/10.1016/j.gsf.2011.11.003

Renard, K. G., Foster, G. R., Weesies, G. A., McCool, D. K., \& Yoder, D. C. (1997). Predicting Soil Erosion by Water: A Guide to Conservation Planning with the Revised Universal Soil Loss Equation (RUSLE). Agricultural Handbook 703, USDA.

Rios, M. (2010). Cartographie des zones sensibles à l'érosion sur le bassin versant de la Vie, du Ligneron et du Jaunay. M.Sc. Thesis, Angers National Centre: Institute of Horticulture and Landscape.

Roose, E. (1977). L'érosion et le ruissellement en Afrique de l'Ouest. Vingt années de mesures dans des parcelles expérimentales. Paris: Collection travaux et documents de l'ORSTOM.

Roose, E., \& Sarrailh, J. M. (1990). Erodibilité de certains sols tropicaux.Vingt années de mesure d'érosion des parcelles de sous les précipitations naturelles. Cah. ORSTOM, 25, 7-30.

Ryan, J. A. (1982). Perspective on Soil Erosion and Conservation in Lebanon. American University of Beirut Publication, 69, 15-38.

Stone, R. P., \& Hilborn, D. (2000). Universal Soil Loss Equation-Factsheet. http://www.omafra.gov.on.ca/english/engineer/facts/00-001.htm

Tagini, B. (1972). Carte géologique de la Côte d'Ivoire (Echelle 1/4 000 000).

Wischmeier, W. H., \& Smith, D. D. (1978). Predicting Rainfall Erosion Losses. Agriculture Handbook 537, Washington DC: USDA.

Xu, L., Xu, X., \& Meng, X. (2012). Risk Assessment of Soil Erosion in Different Rainfall 
Scenarios by RUSLE Model Coupled with Information Diffusion Model: A Case Study of Bohai Rim, China. Catena, 100, 74-82. https://doi.org/10.1016/j.catena.2012.08.012

Yapo, O. (2002). Contribution à l'évolution de l'état trophique du lac de Buyo (Sud-ouest de la Côte d'Ivoire: Étude analytique et statistique des paramètres physico-chimiques et biologiques). PhD Thesis, Abidjan: University of Abobo-Adjame.

Yjjou, M., Bouabid, R., El Hmaidi, A., \& Essahlaoui, A. (2012a). Modelling Water Erosion through the GIS and the Universal Soil Loss Equation at the Watershed of Oum Er-Rbia. In Proceedings of International conference of GIS-Users, GIS-days Taza (pp. 433-435). Fès: Proceeding Book.

Yjjou, M., Bouabid, R., El Hmaidi, A., \& Essahlaoui, A. (2012b). Topographic and Climatic Characterization via GIS Watershed Top Oum Er-Rbia Upstream of the Dam El Hansali (SW Middle Atlas, Morocco). Journal of Hydrocarbons Mines and Environmental Research, 3, 104-109.

Yjjou, M., Bouabid, R., Hmaidi, E, \& Essahlaoui, A. (2014). Modelling Water Erosion via GIS and Universal Soil Loss Equation in the Catchment of the Oum Er-Rbia. The International Journal of Engineering and Science, 3, 83-91.

Yu, B., \& Rosewell, C. J. (1996). Rainfall Erosivity Estimation Using Daily Rainfall Amounts for South Australia. Australian Journal of Soil Research, 34, 721-733. https://doi.org/10.1071/SR9960721

Zhang, X., Wu, B., Ling, F., Zeng, Y, Yan, N., \& Yuan, C. (2010). Identification of Priority Areas for Controlling Soil Erosion. Catena, 83, 76-86.

https://doi.org/10.1016/j.catena.2010.06.012 